\title{
Effects of hypolimnetic aeration on the quantity and quality of settling material in a eutrophied dimictic lake
}

\author{
Juha Niemistö · Soila Silvonen · Jukka Horppila
}

Received: 3 June 2019/Revised: 29 November 2019/Accepted: 10 December 2019/Published online: 21 December 2019

(C) The Author(s) 2019

\begin{abstract}
Effects of hypolimnetic aeration (pumping of epilimnetic water into the hypolimnion) on the quantity of settling material in eutrophied Lake Vesijärvi, Finland were studied by comparing spatially comprehensive gross sedimentation rates as dry and organic matter prior to aeration activity and during two aerated years. Possible changes in the organic matter (as loss on ignition, LOI), carbon (C) and nitrogen $(\mathrm{N})$ contents and changes in the $\mathrm{C} / \mathrm{N}$ ratio of the settling material and surface sediment were quantified. Thermal stratification broke up earlier due to aeration and was followed by sedimentation peaks. The absolute amount of dry and organic matter as well as $\mathrm{C}$ and $\mathrm{N}$ settling to the lake bottom were significantly higher in the aerated years. Increased sedimentation rates were especially pronounced in the deep zones indicating enhanced sediment focusing. Increased sedimentation of $\mathrm{C}$ and $\mathrm{N}$ reflected higher primary production during the aerated years, which most likely was associated with increased temperature and turbulence and the subsequent regeneration and recycling of nutrients in the water body. Aeration
\end{abstract}

Guest editors: Tom Jilbert, Raoul-Marie Couture, Brian J. Huser \& Kalevi Salonen / Restoration of eutrophic lakes: current practices and future challenges

J. Niemistö $(\bowtie) \cdot$ S. Silvonen · J. Horppila

Ecosystems and Environment Research Programme, University of Helsinki, Viikinkaari 1, P.O. Box 65, 00014 Helsinki, Finland

e-mail: juha.niemisto@helsinki.fi seemed to slightly enhance degradation, but contrary to its ultimate aim, it failed to decrease the phosphorus content of the water column and deposits of organic material in the deep zones of the lake.

Keywords Hypolimnetic aeration - Sedimentation rates $\cdot$ Organic matter $\cdot \mathrm{C} / \mathrm{N}$ ratio

\section{Introduction}

Eutrophication of water bodies results in excess production of organic material and increased sedimentation rates (Harper, 1992). Most of the mineralisation of newly produced material may occur already in the water column depending on the depth and trophic level of a lake (Wetzel, 2001). In the long term, however, organic material accumulates on the lake bottom and leads to increased oxygen demand of bottom sediments. In stratifying lakes during stagnation periods, this may result in hypolimnetic oxygen depletion and the associated detrimental consequences (e.g. Harper, 1992; Cooke et al., 2005).

Several different techniques have been applied to increase dissolved oxygen concentrations in lakes suffering from hypoxia or anoxia and to alleviate unwanted symptoms such as fish kills (Moore et al., 2014) or accumulation of redox-dependent metals (manganese, Mn and iron, Fe) as well as harmful and poisonous substances (ammonium, hydrogen 
sulphide, and methylmercury) (Beutel, 2006; Dent et al., 2014). One of the main aims of many such techniques is also to reduce the redox-dependent $\mathrm{P}$ release from sediments to mitigate eutrophication (e.g. Beutel \& Horne, 1999). Improving oxygen conditions in near-bottom waters is considered to rapidly decrease the internal $\mathrm{P}$ loading in cases where iron is abundant in sediments (Mortimer, 1941; Boström et al., 1982). Increased oxygen supply may also enhance mineralisation of organic matter of sediments and subsequently decrease the long-term oxygen demand (Engstrom \& Wright, 2002). This target is often set for an aeration measure, but rarely quantified.

In this study, we explore the effectiveness of hypolimnetic aeration conducted with pumping of oxygen-rich epilimnetic water downwards into the hypolimnion (hereafter mixing aeration) (Lappalainen, 1994; Bendtsen et al., 2013; Salmi et al., 2014). Its ultimate aim is to enhance organic matter mineralisation in sediments via supply of dissolved oxygen, diminish the redox-dependent $\mathrm{P}$ release and consequently remediate the eutrophied water body (Matinvesi, 1996; Salmi et al., 2014). Enhanced mineralisation of settling matter and surface sediment material may be observed as a decrease of their organic content as well as an increase in the $\mathrm{C}$ to $\mathrm{N}$ ratio, since nitrogen-bearing compounds are more easily degraded (Sampei \& Matsumoto, 2001; Gälman et al., 2008). Consequently, the aim of the present study was to assess whether mixing aeration achieves the targets of decreased sedimentation rates of organic matter and an increased $\mathrm{C}$ to $\mathrm{N}$ ratio of settling and surface sediment material in a typical eutrophied shallow lake. The study was conducted in the dimictic Enonselkä basin of Lake Vesijärvi in Southern Finland. Open water period sedimentation rates as dry matter and organic matter were measured during the preceding year (2009) as well as two (2011) and seven years (2016) after the initiation of mixing aeration. Additionally, the quality of settling material as organic matter (loss on ignition, LOI) and the $\mathrm{C}$ to $\mathrm{N}$ ratio of the settling material in the sediment traps and in surface sediments were quantified.

\section{Materials and methods}

Study area

Enonselkä basin (area: $26 \mathrm{~km}^{2}$; mean depth: $6.8 \mathrm{~m}$; max depth: $33 \mathrm{~m}$ ) of Lake Vesijärvi is located in southern Finland $\left(61^{\circ} 01^{\prime} \mathrm{N}, 25^{\circ} 35^{\prime}\right.$ E) (Fig. 1). Normally, the basin is thermally stratified from June to September and shallow non-stratifying areas (depth $<$ $10 \mathrm{~m}$ ) cover $83 \%$ of the total area (Fig. 1). Enonselkä experienced eutrophication mainly due to the sewage effluents received from the city of Lahti until the late 1970s (Keto \& Sammalkorpi, 1988). Various restoration measures, including biomanipulation and diffuse nutrient load reduction, were conducted to mitigate cyanobacterial blooms in the late 1980s and early 1990s (Kairesalo et al., 1999). The most recent measure, mixing aeration, was implemented in 2010 to eliminate the hypolimnetic hypoxia/anoxia and the subsequent redox-dependent internal loading of

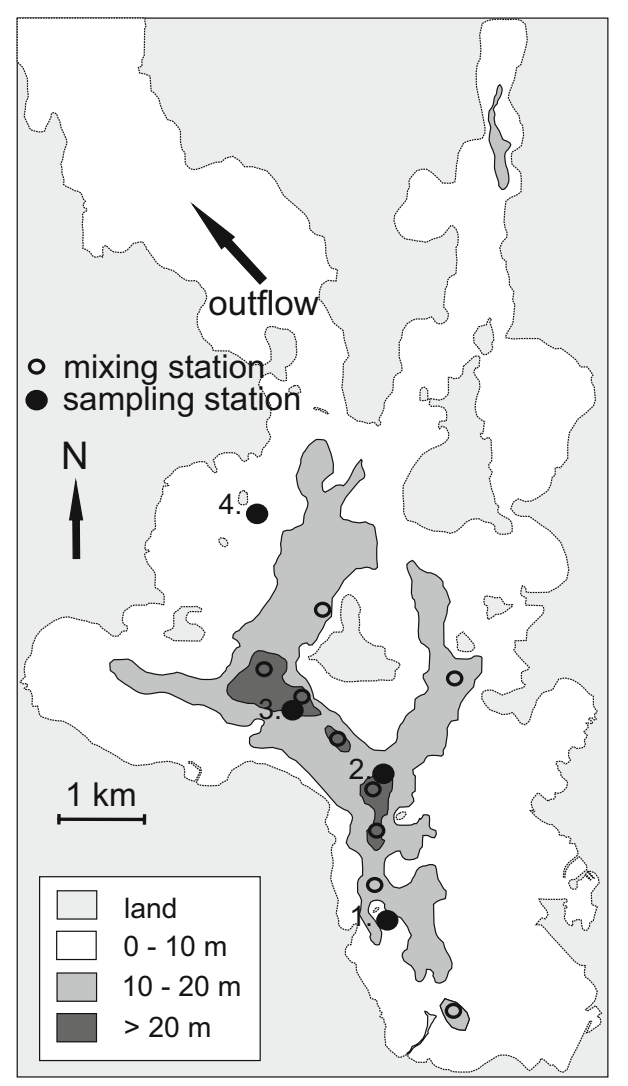

Fig. 1 Map of Enonselkä basin with the depth contours, sampling stations and locations of the aerators 
phosphorus. In the deep zones of the Enonselkä basin, Mixox water pumps (8 Mixox MC-1100 $2.5 \mathrm{~kW}$ and one Mixox MC-750 1.5 kW, Water-Eco Ltd., Kuopio, Finland) have been used to transport oxygen-rich epilimnetic water to the hypolimnion during winter under ice cover (usually from late December to midApril) and summer stratification periods (mid-June to late August) from 2010 to 2017. Since 2017, the pumps have been in operation only in winter time.

Sedimentation and resuspension rates, water temperature, concentration of dissolved oxygen and total phosphorus content of the water column

During the open water seasons of 2009 (reference year), 2011 and 2016 (aerated years), gross sedimentation (GS) was measured at four stations (Fig. 1) with four replicate cylindrical sediment traps (diameter $=5.4 \mathrm{~cm}, h=41 \mathrm{~cm}$ ) suitable for lake conditions (Bloesch \& Burns, 1980). The traps were deployed $2 \mathrm{~m}$ above the lake bottom at shallow non-stratifying stations 1 and 4 (total water depths $8 \mathrm{~m}$ and $6 \mathrm{~m}$, respectively). At the deep stratifying stations 2 and 3 (total water depths $30 \mathrm{~m}$ and $28 \mathrm{~m}$, respectively) traps were deployed at $2 \mathrm{~m}$ above the bottom and at the lower boundary of the epilimnion at a depth of $10 \mathrm{~m}$. The traps were kept in the lake from mid-May to late October/beginning of November and emptied at 14- to 21-day intervals. The dry weight (DW) of entrapped material was measured after drying samples at $105^{\circ} \mathrm{C}$ for three days and the concentration of organic material was determined by loss on ignition (LOI) at $550^{\circ} \mathrm{C}$ for $2 \mathrm{~h}$ (in duplicate from each trap, homogenised samples). The gross sedimentation rate of organic material (settling particulate organic material $=\mathrm{SPOM}$ ) was calculated by multiplying the mean organic matter concentration of the entrapped material by the GS rate at each sampling location.

Resuspension rate was calculated for the deep stations by subtracting the amount of material in epilimnetic traps from the amount of material collected with the near-bottom traps (Bloesch \& Burns, 1980; Bloesch \& Uehlinger, 1986; Koski-Vähälä et al., 2000). Comparison of the near-bottom trap yields of the shallow and deep areas enables the assessment of sediment focusing.

At station 2, the vertical profiles of temperature and dissolved oxygen (DO) were measured with a YSI6600 multiparameter water quality sonde (YSI
Corporation, Yellow Springs, OH, USA) during each sediment sampling occasion. Additionally at station 2, duplicate water samples for the determination of total phosphorus concentration (TP) were collected through the whole water column at $1 \mathrm{~m}$ intervals (Limnos tube sampler, height $1 \mathrm{~m}$, volume $7 \mathrm{l}$ ). Samples for each $10 \mathrm{~m}$-thick water layer were pooled (0-10 m, 10-20 m and 20-30 m), determined spectrophotometrically for total phosphorus (Lachat autoanalyzer 8000 Series, ammonium molybdenum blue method) and the total phosphorus content of each water layer was calculated based on their proportional volume of the total volume of Enonselkä basin (0-10 m: 87\%; 10-20 m: 12\%; 20-30 m: 1.3\%).

Organic matter, carbon and nitrogen concentrations of the surface sediment and entrapped material

Surface sediment samples (topmost $0-1 \mathrm{~cm}$, duplicate samples) were collected with an HTH gravity corer (inner diameter $86 \mathrm{~mm}$ ) (Renberg \& Hansson, 2008) from each station on each sampling occasion when the sediment traps were emptied. The concentration of organic material (as LOI) in the dried surface sediment samples was determined as described above for the entrapped material. The concentration of carbon (C) and nitrogen (N) in the surface sediment and entrapped material was determined from duplicate samples dried at $60^{\circ} \mathrm{C}$ with a $\mathrm{CHN}$ analyser (Leco TruSpec Micro, US).

\section{Statistical analysis}

The normality of the data sets was verified with the Shapiro-Wilk test. Since the datasets were nonnormally distributed, the differences in sedimentation rates (GS, SPOM, C and N) and in the quality of the settling and surface sediment material (LOI and $\mathrm{C} / \mathrm{N}$ ratio) between the different years and water depths were tested with Kruskal-Wallis analysis (paired comparisons conducted with Mann-Whitney test with Bonferroni correction, $\alpha=0.05$ ). In addition, the differences in resuspension rates as a percentage of the GS $\left(\arcsin x^{-0.5}\right.$ transformed data) between the years 2009 and 2016 were tested with Kruskal-Wallis analysis (SAS Institute Inc., 2008). The difference between the total phosphorus content of the water column between the studied years was tested with 
analysis of variance for repeated measurements (SAS Institute Inc., 2008).

\section{Results}

Temperature and oxygen concentrations

In 2009, the water column of Enonselkä basin was thermally stratified from mid-May to late September (Fig. 2). In the course of the development of stratification, the DO concentration in the hypolimnion decreased and oxygen was depleted from mid-June to mid-September (Fig. 3). In 2011 and 2016, stratification was strongly affected during the mixing aeration period. The temperature difference between the epilimnion and hypolimnion was smaller, and hypolimnetic temperature was $2-5^{\circ} \mathrm{C}$ higher than in the reference year. Additionally, the overturn period started earlier in the aerated years (Fig. 2). In the warm summer of 2011 (Table 1), destratification occurred in late August at a temperature of $15^{\circ} \mathrm{C}$. In the cooler summer of 2016 (Table 1), the lake destratified before mid-August at a temperature of $17^{\circ} \mathrm{C}$, which was $6-7^{\circ} \mathrm{C}$ higher than in the reference year. Despite the aeration, hypolimnetic oxygen depletion was not avoided in 2011. In 2016, dissolved oxygen was not depleted during the short stagnation period, but decreased to $2 \mathrm{mg} \mathrm{l}^{-1}$ below the $20 \mathrm{~m}$ depth.
Total phosphorus content of the water column

After the initiation of aeration, the accumulation of total phosphorus in the deeper layer of the hypolimnion, 20-30 m, was not observed in late summer as in the reference year 2009 (370 kg 1 Sept in 2009 vs $143 \mathrm{~kg} 24$ Aug in 2011 and $110 \mathrm{~kg} 30 \mathrm{Aug}$ in 2016) (Fig. 4c). However, the TP content of this water layer did not statistically differ from the aerated years when the whole open water season was taken into account (ANOVA for repeated measures: $F_{10}=1.29$, $P=0.317)$. Similarly, in the upper hypolimnion, 10-20 m, no differences were observed $\left(\mathrm{F}_{10}=3.16\right.$, $P=0.086$ ) (Fig. 4b). The TP content of the epilimnion $(0-10 \mathrm{~m})$ in turn was significantly higher during both aerated years (range $3606-5680 \mathrm{~kg}$ in 2011 and $3146-6981 \mathrm{~kg}$ in 2016) than in the reference year (range $2817-5244 \mathrm{~kg})\left(\mathrm{F}_{10}=15.00, P=0.001\right)$ (Fig. 4a). During the aerated period, from mid-June to mid-August, when the difference was most pronounced (Fig. 4a), the TP content was 19 to $75 \%$ higher in 2011 and 13 to $44 \%$ higher in 2016 than in 2009.

Sedimentation rates of dry matter (GS), organic matter (SPOM), nitrogen and carbon

The temporal pattern of gross sedimentation rates as dry matter (GS) was similarly coupled to thermal stratification in each studied year. In the deep areas, sedimentation peaked in early summer and especially
Fig. 2 Water temperature $\left({ }^{\circ} \mathrm{C}\right)$ (isotherms) at station 2 for the reference year a 2009 and aerated years $\mathbf{b} 2011$ and c 2016

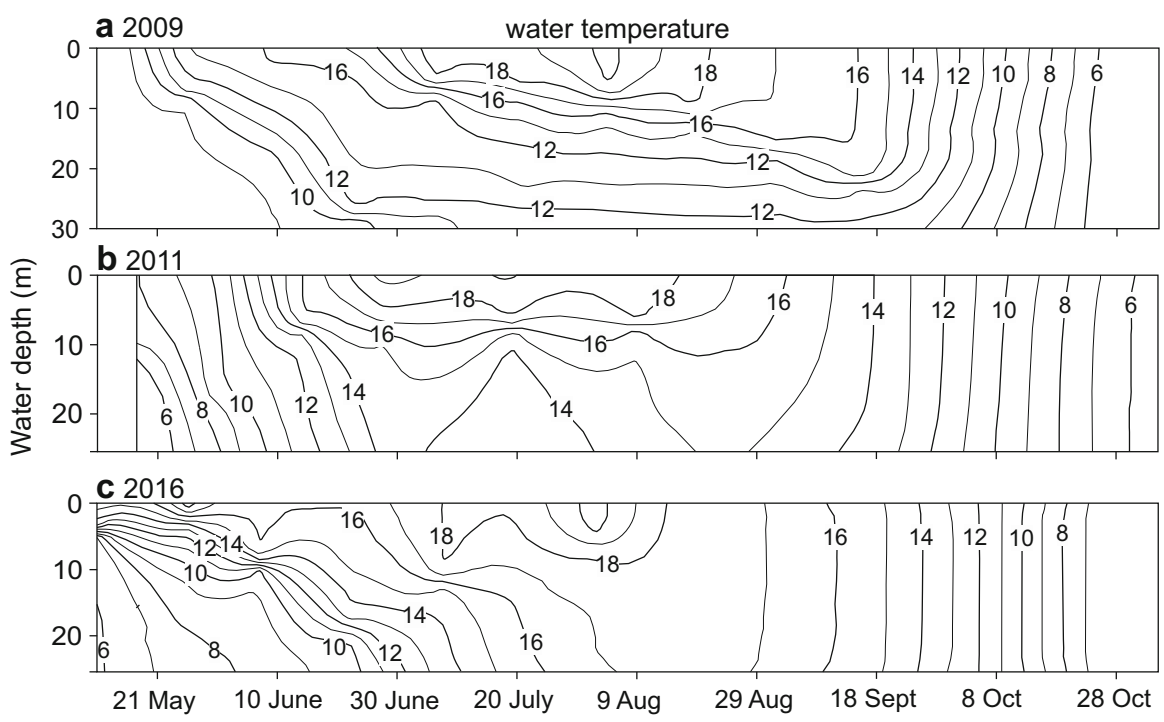


Fig. 3 Concentration of dissolved oxygen $\left(\mathrm{mg} \mathrm{l}^{-1}\right)$ (isolines) at station 2 for the reference year a 2009 and aerated years b 2011 and c 2016

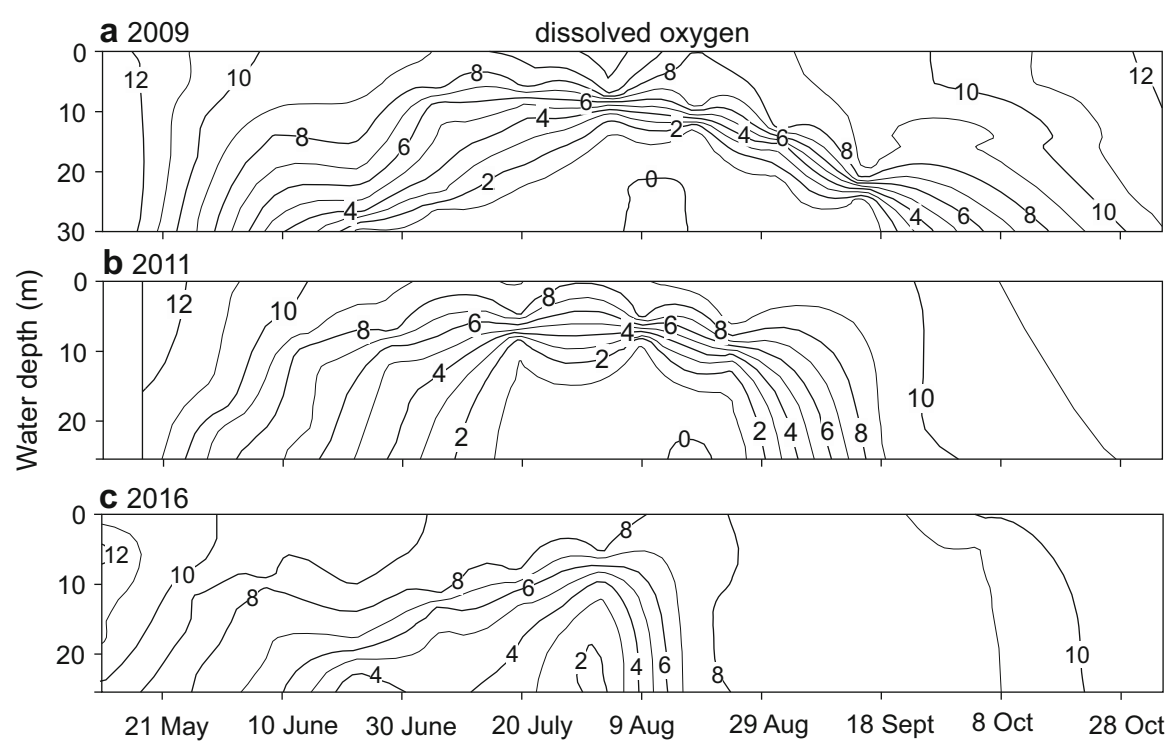

Table 1 Mean monthly air temperatures $\left({ }^{\circ} \mathrm{C}\right)$ during the study periods in 2009, 2011 and 2016 (data from Weather observation archive of Finnish Meteorological Institute, Laune observation station)

\begin{tabular}{lrrr}
\hline Month/year & 2009 & 2011 & 2016 \\
\hline May & 11.2 & 10.4 & 12.9 \\
June & 13.6 & 16.7 & 15.1 \\
July & 16.7 & 20.1 & 16.8 \\
August & 15.1 & 16.0 & 14.8 \\
September & 11.4 & 11.9 & 11.1 \\
October & 2.1 & 6.2 & 3.7 \\
\hline
\end{tabular}

after destratification, which occurred considerably earlier in 2016 than in other years (Fig. 5b, c). In shallow areas and in the epilimnion of the deep areas, the highest sedimentation peaks were also observed after destratification, and again, earlier in 2016 than in other years (Fig. 5a). The sedimentation rates of organic material (SPOM), carbon (C) and nitrogen (N) closely followed that of gross sedimentation in each year (data on temporal variation of SPOM, C and $\mathrm{N}$ not shown).

In both years when aeration was performed, the median rate values of GS and SPOM for the deep areas based on the near-bottom traps (GS: 31.4 and $59.7 \mathrm{~g} \mathrm{~m}^{-2} \mathrm{~d}^{-1}$; SPOM: 4.6 and $10.3 \mathrm{~g} \mathrm{~m}^{-2} \mathrm{~d}^{-1}$ in 2011 and 2016 respectively) were significantly higher than in 2009 (GS: $18.2 \mathrm{~g} \mathrm{~m}^{-2} \mathrm{~d}^{-1}$, SPOM: $3.2 \mathrm{~g} \mathrm{~m}^{-2}$ $\mathrm{d}^{-1}$ ) (Tables 2 and 3). In 2016, when the sedimentation rates peaked already in late August, the SPOM rate was also higher compared to 2011 (Table 3). Consequently, statistically highest median values were measured also for $\mathrm{C}$ and $\mathrm{N}$ sedimentation rates in 2016. The GS and SPOM rates measured from the epilimnetic traps were also markedly higher in 2016 than in 2009 (GS: 6.3 vs $16.4 \mathrm{~g} \mathrm{~m}^{-2} \mathrm{~d}^{-1}$; SPOM: 1.2 vs $2.3 \mathrm{~g} \mathrm{~m}^{-2} \mathrm{~d}^{-1}$ (Tables 2 and 3) (C and $\mathrm{N}$ rates not determined due to the lack of material in the epilimnetic traps). In the shallow areas, the sedimentation rates of different parameters were not consistently affected by aeration. The GS rate was higher in 2011 and 2016 than in 2009, but only the SPOM rate of 2016 differed from that of the reference year (Tables 2 and 3).

Resuspension rate as a percentage of GS ranged from 30 to $88 \%$ and from 53 to $83 \%$ in 2009 and 2016, respectively, and showed no statistical difference $\left(X^{2}=2.70, d f=1, P=0.100\right)$ (Fig. 6). However, resuspension rates seemed to be higher in July-August in 2016, when the destratification occurred earlier in summer.

Organic content and $\mathrm{C}$ to $\mathrm{N}$ ratio of the surface sediment and entrapped material

The organic content of the surface sediment showed only a minor variation between the studied years. In 

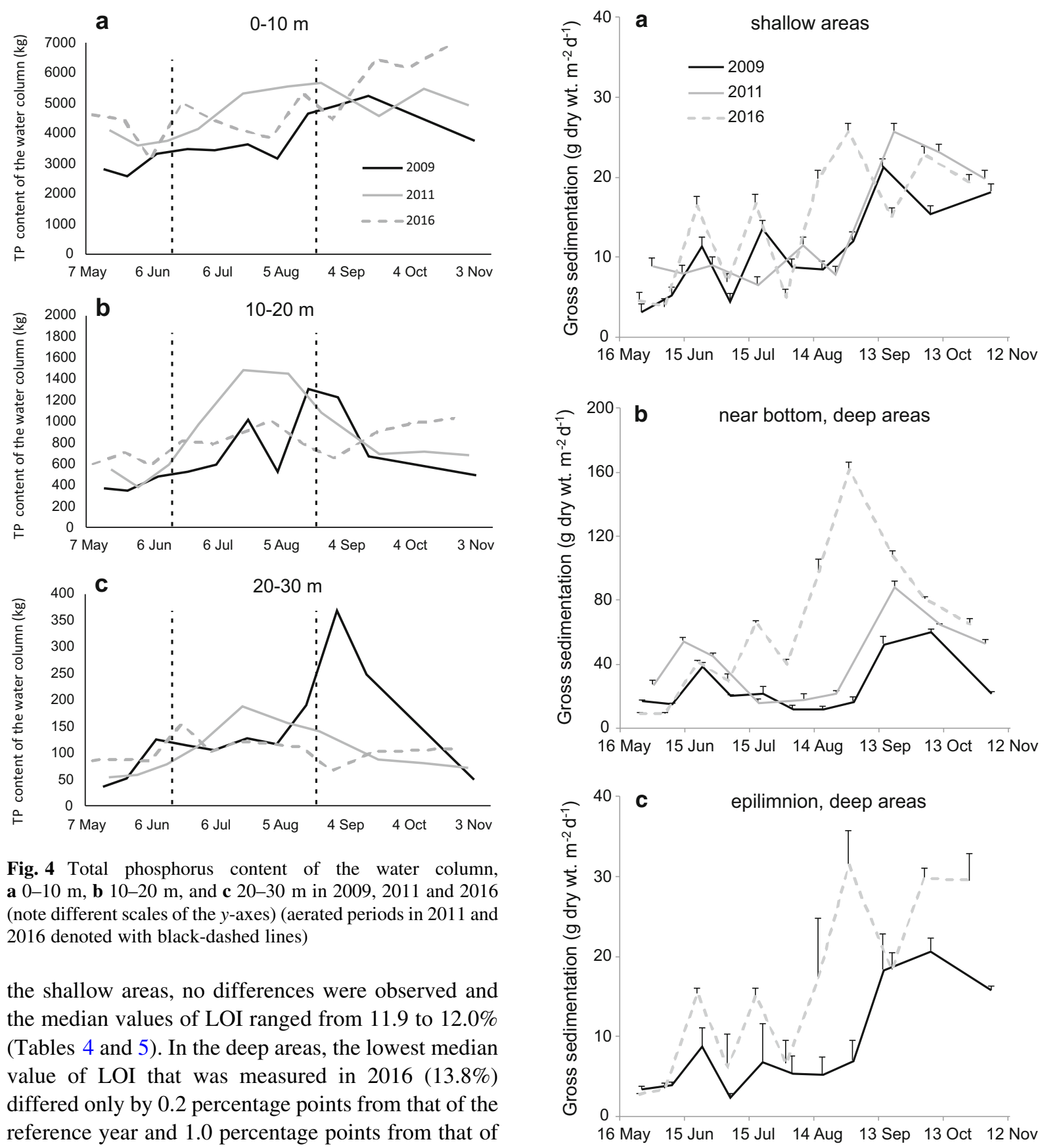

Fig. 4 Total phosphorus content of the water column, a $0-10 \mathrm{~m}$, b $10-20 \mathrm{~m}$, and c 20-30 m in 2009, 2011 and 2016 (note different scales of the $y$-axes) (aerated periods in 2011 and 2016 denoted with black-dashed lines)

the shallow areas, no differences were observed and the median values of LOI ranged from 11.9 to $12.0 \%$ (Tables 4 and 5). In the deep areas, the lowest median value of LOI that was measured in 2016 (13.8\%) differed only by 0.2 percentage points from that of the reference year and 1.0 percentage points from that of 2011 (14.8\%), that was the highest of all years. The C to $\mathrm{N}$ ratio of the surface sediment in turn showed no difference between the studied years in the deep areas. In the shallow areas, the $\mathrm{C}$ to $\mathrm{N}$ ratio showed the highest median value of 9.7 in the reference year, however, the difference between this value and those of 2011 (9.5) and 2016 (9.7) was minor (Tables 4 and $5)$.

Fig. 5 Temporal development of the gross sedimentation rates (mean of two stations + SD) in the shallow areas (a) in nearbottom (b) and epilimnion (c) of the deep areas in 2009, 2011 and 2016

The organic content of the settling material collected from the sediment traps was lower in both the deep (near-bottom: $15.4 \%$ vs $16.2 \%$ ) and shallow 
Table 2 Median values and ranges of gross sedimentation $\left(\mathrm{g} \mathrm{m}^{-2} \mathrm{~d}^{-1}\right)$ as dry weight (GS), organic material (SPOM), carbon (C) and nitrogen $(\mathrm{N})$ in the reference year 2009 and aerated years 2011 and 2016 (no epilimnetic traps deployed in 2011)

na No data available

\begin{tabular}{|c|c|c|c|c|c|c|}
\hline & \multicolumn{2}{|l|}{2009} & \multicolumn{2}{|l|}{2011} & \multicolumn{2}{|l|}{2016} \\
\hline & Median & Range & Median & Range & Median & Range \\
\hline \multicolumn{7}{|l|}{ Deep areas } \\
\hline $\mathrm{GS}_{\text {bottom }}$ & 18.2 & $10.6-70.0$ & 31.4 & $14.0-92.3$ & 59.7 & $8.3-184.9$ \\
\hline $\mathrm{GS}_{\text {epilimnion }}$ & 6.3 & $2.0-22.0$ & na & na & 16.4 & $2.3-35.4$ \\
\hline SPOM $_{\text {bottom }}$ & 3.2 & $1.8-11.5$ & 4.6 & $2.3-14.4$ & 10.3 & $1.7-27.3$ \\
\hline $\mathrm{SPOM}_{\text {epilimnion }}$ & 1.2 & $0.4-3.8$ & na & na & 2.3 & $0.6-6.6$ \\
\hline $\mathrm{C}_{\text {bottom }}$ & 1.5 & $0.9-5.0$ & 1.8 & $0.8-5.4$ & 3.9 & $0.6-10.6$ \\
\hline $\mathrm{N}_{\text {bottom }}$ & 0.2 & $0.1-0.6$ & 0.2 & $0.1-0.5$ & 0.4 & $0.1-1.1$ \\
\hline \multicolumn{7}{|l|}{ Shallow areas } \\
\hline GS & 8.6 & $2.3-29.3$ & 11.2 & $2.2-31.4$ & 15.9 & $2.8-29.5$ \\
\hline SPOM & 1.6 & $0.7-4.8$ & 1.8 & $0.8-4.4$ & 2.3 & $0.6-5.1$ \\
\hline $\mathrm{C}$ & 0.9 & $0.3-1.9$ & 0.7 & $0.3-1.8$ & 0.9 & $0.2-1.9$ \\
\hline $\mathrm{N}$ & 0.1 & $0.04-0.2$ & 0.1 & $0.04-0.2$ & 0.1 & $0.02-0.2$ \\
\hline
\end{tabular}

areas (15.3\% vs $17.6 \%)$ in 2011 than in the reference year (Tables 4 and 5). In the deep areas, the median value of 2011 differed statistically significantly also from the median value of 2016, $17.3 \%$ (Tables 4 and 5). Correspondingly, the $\mathrm{C}$ to $\mathrm{N}$ ratio of the entrapped material of the deep and shallow areas was highest in 2011. However, the quality of settling material as LOI or $\mathrm{C}$ to $\mathrm{N}$ ratio showed no difference between the reference year and the latter aerated year 2016 in either deep or shallow areas (Tables 4 and 5).

The organic content of the entrapped material collected from the epilimnion was lower in 2016 $(17.5 \%)$ than in $2009(18.5 \%)\left(X^{2}=5.08, d f=1\right.$, $P<0.0242$ ), but did not differ from that of the nearbottom traps of the deep areas in $2016\left(X^{2}=2.09\right.$, $d f=1, P=0.1479$ ). In 2009, in turn, the near-bottom traps collected less organic material $(16.2 \%)$ than the epilimnetic traps $\left(X^{2}=32.41, d f=1, P<0.0001\right)$ (Tables 4 and 5).

\section{Discussion}

Aeration-induced increases in sedimentation rates

Sedimentation rates of a lake can increase due to increased allochthonous load of settling material, increased autochthonous production or enhanced sediment resuspension (e.g. Bloesch \& Uehlinger, 1986). The strong increase in the sedimentation rates as dry and organic matter in Enonselkä during the aerated years (1.7- and 3.3-fold GS rates, and 1.4- and 3.2-fold SPOM rates in 2011 and 2016, respectively) was unlikely due to increased allochthonous load of material, since any major increase in the load (minerogenic or organic) would have affected the quality of settling material (i.e. $\mathrm{C} / \mathrm{N}$ ratio) (Hansen, 1961; Engstrom \& Wright, 2002), which was not the case (see "Effect of aeration on nutrient recycling and on $\mathrm{LOI}$ and $\mathrm{C} / \mathrm{N}$ ratio of the settling material and surface sediment" section). Additionally, the external load of phosphorus was at the same level or smaller in the aerated years (2011: $4270 \mathrm{~kg} \mathrm{P} \mathrm{a}^{-1} ; 2016: 3740 \mathrm{~kg}$ $\mathrm{P} \mathrm{a}^{-1}$ ) than in 2009 (4270 $\mathrm{kg} \mathrm{P} \mathrm{a}^{-1}$ ) (the calculation method for the external load of $\mathrm{P}$ is presented in Niemistö et al., 2016 and Tattari \& Linjama, 2004). Aeration-induced increases in resuspension rates have not been recognised in earlier basin-scale studies conducted in Enonselkä, although such possibility has been discussed due to the effect of the mixing aeration on the water column stability (Salmi et al., 2014; Niemistö et al., 2016). In the present study, the resuspension rate as a percentage of GS was estimated only for the deep areas and no statistically significant difference between the years 2009 and 2016 was observed. However, the temporal development of the resuspension rates seemed to differ between the years. In 2016, when the destratification occurred before mid-August and stratification was weak already during July, resuspension rate was higher during the summer months compared to the reference year. 
Table 3 Statistical results of Kruskal-Wallis test on the differences in gross sedimentation rates of dry matter (GS), organic material (SPOM), carbon (C) and nitrogen (N) between the studied years 2009, 2011 and 2016, as well as results of pairwise comparisons (Mann-Whitney test)

\begin{tabular}{|c|c|c|c|c|c|c|}
\hline & \multicolumn{2}{|c|}{$d f$} & \multicolumn{2}{|l|}{$X^{2}$} & $P$ & $n$ \\
\hline \multicolumn{7}{|l|}{ Deep areas } \\
\hline $\mathrm{GS}_{\text {bottom }}$ & 2 & \multicolumn{3}{|c|}{38.7} & $<0.001$ & 207 \\
\hline $\mathrm{GS}_{\text {epilimnion }}$ & 1 & \multicolumn{3}{|c|}{19.06} & $<0.001$ & 164 \\
\hline $\mathrm{SPOM}_{\text {bottom }}$ & 2 & \multicolumn{3}{|c|}{46.2} & $<0.001$ & 207 \\
\hline $\mathrm{SPOM}_{\text {epilimnion }}$ & 1 & \multicolumn{3}{|c|}{21.65} & $<0.001$ & 164 \\
\hline $\mathrm{C}_{\text {bottom }}$ & 2 & \multicolumn{3}{|c|}{23.3} & $<0.001$ & 186 \\
\hline $\mathrm{N}_{\text {bottom }}$ & 2 & \multicolumn{3}{|c|}{25.2} & $<0.001$ & 186 \\
\hline \multicolumn{7}{|l|}{ Shallow areas } \\
\hline GS & 2 & \multicolumn{3}{|c|}{10.5} & 0.006 & 232 \\
\hline SPOM & 2 & \multicolumn{3}{|c|}{6.6} & 0.037 & 232 \\
\hline $\mathrm{C}$ & 2 & \multicolumn{3}{|c|}{0.1} & 0.930 & 196 \\
\hline $\mathrm{N}$ & 2 & \multicolumn{3}{|c|}{0.3} & 0.844 & 196 \\
\hline \multicolumn{2}{|c|}{ Pairwise comparisons } & \multicolumn{3}{|l|}{ Deep areas } & \multicolumn{2}{|c|}{ Shallow areas } \\
\hline & Years & $X^{2}$ & & $P$ & $X^{2}$ & $P$ \\
\hline \multirow[t]{3}{*}{$\mathrm{GS}_{\text {bottom }}$} & 2009-2011 & -34.105 & & 0.007 & -29.165 & 0.029 \\
\hline & 2009-2016 & -58.517 & & 0.000 & -30.384 & 0.010 \\
\hline & 2011-2016 & -24.413 & & 0.082 & -1.220 & 1.000 \\
\hline \multirow[t]{3}{*}{ SPOM $_{\text {bottom }}$} & 2009-2011 & -30.620 & & 0.019 & -21.190 & 0.180 \\
\hline & 2009-2016 & -63.954 & & 0.000 & -25.128 & 0.045 \\
\hline & 2011-2016 & -33.334 & & 0.008 & -3.938 & 1.000 \\
\hline \multirow[t]{3}{*}{$\mathrm{C}_{\text {bottom }}$} & 2009-2011 & -5.861 & & 1.000 & & \\
\hline & 2009-2016 & -40.641 & & 0.000 & & \\
\hline & 2011-2016 & -34.780 & & 0.001 & & \\
\hline \multirow[t]{3}{*}{$\mathrm{N}_{\text {bottom }}$} & 2009-2011 & -0.173 & & 1.000 & & \\
\hline & 2009-2016 & -39.901 & & 0.000 & & \\
\hline & 2011-2016 & -39.728 & & 0.000 & & \\
\hline
\end{tabular}

Increased sedimentation rates due to resuspension and sediment focusing are common during periods of weak stability or during overturn, when conditions are more turbulent (Likens \& Davis, 1975; Bloesch \& Uehlinger, 1986; Blais \& Kalff, 1995). Such development was observed also in Enonselkä during all the studied years as the peaks of sedimentation rates as dry and organic matter in the deep and shallow areas always followed destratification. Additionally, the sedimentation peaks occurred earlier and were higher in the aerated years. Thus, we conclude that the mixing aeration, through weaker stratification and earlier destratification, leads to enhanced resuspension and redistribution of sediments. An explanation for the non-significant difference in the resuspension rate

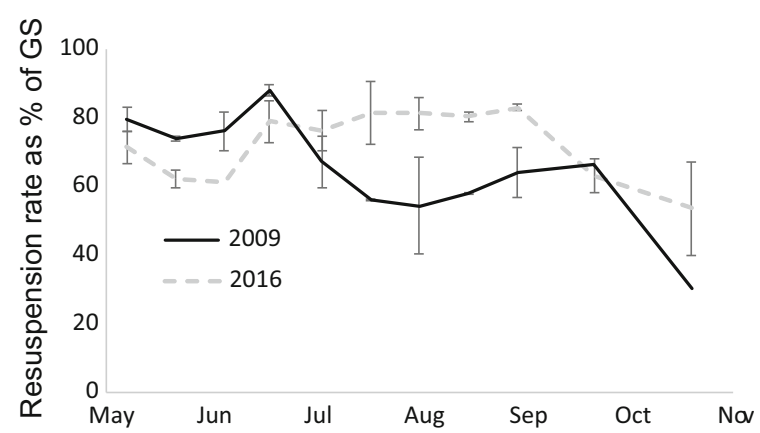

Fig. 6 Resuspension rate as a percentage of GS at the deep areas (mean of two stations \pm SD) in 2009 and 2016 calculated as the difference between the material yield of near-bottom and epilimnetic traps 
Table 4 Median values and ranges of $\mathrm{LOI}$ and $\mathrm{C} / \mathrm{N}$ ratio of the surface sediment and entrapped material in reference year 2009 and aerated years 2011 and 2016 (no epilimnetic traps deployed in 2011)

na No data available

\begin{tabular}{|c|c|c|c|c|c|c|}
\hline & \multicolumn{2}{|l|}{2009} & \multicolumn{2}{|l|}{2011} & \multicolumn{2}{|l|}{2016} \\
\hline & Median & Range & Median & Range & Median & Range \\
\hline \multicolumn{7}{|l|}{ Deep areas } \\
\hline Surf. sed., LOI (\%) & 14.0 & $13.1-17.9$ & 14.8 & $11.5-15.7$ & 13.8 & $12.8-16.5$ \\
\hline Surf. sed., C/N & 9.5 & $8.7-10.1$ & 9.6 & $8.8-10.4$ & 9.4 & $9.0-10.0$ \\
\hline Trap bottom, LOI (\%) & 16.2 & $14.6-24.4$ & 15.4 & $13.6-18.7$ & 17.3 & $12.6-26.4$ \\
\hline Trap $_{\text {epilim., LOI }(\%)}$ & 18.5 & $15.2-33.1$ & na & na & 17.5 & $13.2-28.0$ \\
\hline Trap $_{\text {bottom }}, \mathrm{C} / \mathrm{N}$ & 9.1 & $7.7-10.5$ & 9.6 & $8.8-12.0$ & 9.3 & $7.2-10.1$ \\
\hline \multicolumn{7}{|l|}{ Shallow areas } \\
\hline Surf. sed., LOI (\%) & 11.9 & $10.8-14.3$ & 11.9 & $11.0-15.0$ & 12.0 & $10.9-14.6$ \\
\hline Surf. sed., C/N & 9.7 & $8.7-10.8$ & 9.5 & $8.8-10.2$ & 9.6 & $9.1-10.1$ \\
\hline Trap, LOI (\%) & 17.6 & $12.4-42.8$ & 15.3 & $13.0-40.4$ & 16.2 & $12.4-27.6$ \\
\hline Trap, C/N & 8.9 & $8.0-10.3$ & 9.3 & $5.9-12.0$ & 9.0 & $7.0-10.1$ \\
\hline
\end{tabular}

estimates between 2009 and 2016 could be that a part of the material resuspended in shallow areas reached the epilimnetic traps in the deep areas due to horizontal currents created by winds. Consequently, the rate estimates based on the difference between the near-bottom and epilimnetic trap yields were affected. Accordingly, wind-driven redistribution of sediments (Buhvestova et al., 2013) and capture of resuspended material in epilimnetic traps (Koski-Vähälä et al., 2000) have previously been observed in Enonselkä, and this process was most likely enhanced when aerators decreased the stability of the water column (Horppila et al., 2017). Additionally, it is possible that the functioning of the aerators (including the generation of warm epilimnetic water plumes moving upwards in the vicinity of the aerators, e.g. Salmi et al., 2014) mixed settling particles from the deeper water layers back to the lower border of epilimnion. Moreover, we have to refine our previous conclusions (Niemistö et al., 2016) that resuspension rates were not affected by mixing aeration. We would rather state that the increase in resuspension rates was not detected with the method used in the present study or with the label method (Gasith, 1975) used by Niemistö et al. (2016). The label method is based on the difference in the organic content between suspended solids, trap material and surface sediment. Mixing aeration is equalizing the quality of settling material in the water column (see "Effect of aeration on nutrient recycling and on LOI and $\mathrm{C} / \mathrm{N}$ ratio of the settling material and surface sediment" section), thus resulting in underestimation of the resuspension rate. However, the increased GS rates were not solely due to enhanced redistribution and sediment focusing, since the increased SPOM rates recorded from the shallow areas and from the epilimnetic traps of the deep areas suggested that primary production was also enhanced in 2016, when the destratification occurred in the middle of growth season. Additionally, the increased sedimentation rates of $\mathrm{C}$ and $\mathrm{N}$ measured from the near-bottom traps of the deep stations indicated that higher total amount of organic settling material was likely produced and redistributed in that year.

Effect of aeration on nutrient recycling and on LOI and $\mathrm{C} / \mathrm{N}$ ratio of the settling material and surface sediment

Total phosphorus content of the epilimnion was higher during both aerated years than in the reference year, and this could not result from the changes in the external load. This provides strong evidence that via altered redistribution of settling material, mixing aeration affected also phosphorus cycling. An increase in the TP content of the epilimnion in turn most likely enabled excess production of organic material. Longterm records of chlorophyll a concentrations did not indicate strong changes in the phytoplankton biomass, but the concentration in 2016 was among the highest observed during the last 30 years (Kuoppamäki, 2016; Ruuhijärvi et al., 2019). Additionally in that year, the biomass of cyanobacteria was highest among the aerated years or higher than in most of the 10 years 
Table 5 Statistical results of Kruskal-Wallis test on the differences in LOI and C/N ratio of the surface sediment and entrapped material between years 2009, 2011 and 2016, as well as results of pairwise comparisons (Mann-Whitney test)

\begin{tabular}{|c|c|c|c|c|c|}
\hline & $d f$ & $X^{2}$ & \multicolumn{2}{|c|}{$P$} & $n$ \\
\hline \multicolumn{6}{|l|}{ Deep areas } \\
\hline Surf. sed., LOI & 2 & 13.7 & \multicolumn{2}{|c|}{0.001} & 212 \\
\hline Surf. sed., C/N & 2 & 4.9 & \multicolumn{2}{|c|}{0.086} & 236 \\
\hline Trap $_{\text {bottom }}$, LOI & 2 & 14.2 & \multicolumn{2}{|c|}{0.001} & 207 \\
\hline Trap $_{\text {epilim., LOI }}$ & 1 & 5.08 & \multicolumn{2}{|c|}{0.024} & 164 \\
\hline Trap $_{\text {bottom }}, \mathrm{C} / \mathrm{N}$ & 2 & 25.0 & \multicolumn{2}{|c|}{$<0.001$} & 186 \\
\hline \multicolumn{6}{|l|}{ Shallow areas } \\
\hline Surf. sed., LOI & 2 & 3.8 & \multicolumn{2}{|c|}{0.151} & 238 \\
\hline Surf. sed., C/N & 2 & 14.7 & \multicolumn{2}{|c|}{0.001} & 238 \\
\hline Trap, LOI & 2 & 11.3 & \multicolumn{2}{|c|}{0.004} & 232 \\
\hline Trap, C/N & 2 & 9.9 & \multicolumn{2}{|c|}{0.007} & 196 \\
\hline \multicolumn{2}{|l|}{ Pairwise comparisons } & \multicolumn{2}{|l|}{ Deep areas } & \multicolumn{2}{|c|}{ Shallow areas } \\
\hline & Years & $X^{2}$ & $P$ & $X^{2}$ & $P$ \\
\hline \multirow[t]{3}{*}{ Surface sed., $\mathrm{LOI}_{\text {bottom }}$} & 2009-2011 & -10.984 & 1.000 & & \\
\hline & 2009-2016 & 26.228 & 0.017 & & \\
\hline & 2011-2016 & 37.212 & 0.003 & & \\
\hline \multirow[t]{3}{*}{ Surface sed., $\mathrm{C} / \mathrm{N}_{\text {bottom }}$} & 2009-2011 & & & 43.214 & 0.001 \\
\hline & 2009-2016 & & & 29.403 & 0.020 \\
\hline & 2011-2016 & & & -13.811 & 0.634 \\
\hline \multirow[t]{3}{*}{ Trap material, $\mathrm{LOI}_{\text {bottom }}$} & 2009-2011 & 31.246 & 0.017 & 37.587 & 0.003 \\
\hline & 2009-2016 & -10.457 & 0.787 & 20.427 & 0.146 \\
\hline & 2011-2016 & -41.703 & 0.001 & -17.160 & 0.376 \\
\hline \multirow[t]{3}{*}{ Trap material, $\mathrm{C} / \mathrm{N}_{\text {bottom }}$} & 2009-2011 & -51.075 & $<0.001$ & -28.203 & 0.031 \\
\hline & 2009-2016 & -3.259 & 1.000 & 0.491 & 1.000 \\
\hline & 2011-2016 & 47.816 & $<0.001$ & 28.694 & 0.031 \\
\hline
\end{tabular}

preceding the aeration measure (Ruuhijärvi et al., 2019).

Based on the GS rates and LOI determinations, the absolute amount of organic material settling to the bottom in the deep area of Enonselkä strongly increased after the initiation of aeration, although the proportion of the organic component in the settling material showed no major changes. This could be considered as evidence for simultaneous increase in primary production and enhanced degradation of organic material. In general, the organic content of the settling material decreases and the $\mathrm{C} / \mathrm{N}$ ratio increases with water depth during the sedimentation process, because nitrogen compounds are degraded faster (Koyama \& Tomino, 1967; Pennington \& Tutin, 1974; Jones, 1976). Indicative of enhanced degradation were the lowest LOI values and the highest $\mathrm{C} / \mathrm{N}$ ratio values (differences were minor, but statistically significant) observed from the near-bottom traps in the warm summer of 2011, when the hypolimnetic water temperature was higher than in the reference year. In addition to higher temperature (Rose, 1967; Jones, 1976), the aeration-induced increase in turbulence may enhance the degradation of organic material in the water column by increasing the settling time of particles (Ashley, 1983; Gantzer et al., 2009; Niemistö et al., 2016). Mixing aeration affects temperature (Salmi et al., 2014; Holmroos et al., 2016; Kuha et al., 2016) and additionally increases turbulence in the hypolimnion at least $200 \mathrm{~m}$ from the aerator (Niemistö et al., 2016). Despite the significant effect of aeration on the trap material in 2011, no difference in the quality of settling material in near-bottom traps of the deep areas between 2009 and 2016 was detected. This 
was most likely due to weaker stratification and earlier breakup of stagnation that resulted in higher resuspension and redistribution of sediments, thereby masking the effects of enhanced degradation. The significant difference in the LOI values between epilimnetic and hypolimnetic trap material in 2009, but the lack of such a difference in 2016, also provided evidence for the equalizing effect of aerators on the quality of settling material during the study period with the lowest water column stability. Altogether, strong mixing of the hypolimnion, weakening of water column stability and enhanced degradation of organic material inevitably resulted also in the enhanced recycling of nutrients in the water column, which likely contributed to the increase of TP content in the epilimnion.

Together with increased temperature and turbulence the excess supply of oxygen provided to the hypolimnion by the aerators, as seen in 2011 and especially in 2016, contributes to the efficiency of bacterial degradation (e.g. Mardsen, 1989) not only in the water column but also possibly in the surface sediment (Marsden, 1989, Jensen \& Andersen, 1992; Bergström et al., 2010). Such a result is one key aim of this restoration measure, but unfortunately, it seems that when the mixing aeration is more efficient in degrading organic material, its weakening effect on water column stability may also lead to excess primary production. In the deep zones of the lake, the median value of organic content of the surface sediment was $0.2 \%$ units lower in 2016 than in 2009, but the $\mathrm{C} / \mathrm{N}$ ratio remained the same. Additionally in 2011, when the entrapped material showed the lowest LOI values, the organic content of the surface sediment was higher ( $0.8 \%$ units) than in 2009. Therefore, there is no clear indication that mixing aeration would lead to decreased deposits of more degraded material that would be indicated by lower LOI values and higher $\mathrm{C} / \mathrm{N}$ ratio values (Koyama \& Tomino, 1967; Sampei \& Matsumoto, 2001; Gälman et al., 2008) in the deep zones of the lake. Most importantly, as mentioned above, the SPOM rates of the shallow areas and epilimnion of the deep areas also strongly increased. Thus, we conclude that by mixing aeration, it is not possible to decrease internal $\mathrm{P}$ loading in such a way that it would result in oligotrophication in Lake Vesijärvi. In fact, the contrary seems to occur in the Enonselkä basin due to enhanced phosphorus recycling in the water column. Our results can partially explain the earlier ineffective attempts to mitigate eutrophic conditions by long-term mixing aeration e.g. in Lake Jyväsjärvi (Kuha et al., 2016) as well as provide evidence why the total internal $\mathrm{P}$ loading in Lake Tuusulanjärvi (load estimates were based on a modelling approach) has remained at the same level during 20 years of aeration (Horppila et al., 2017).

In the warm summer of 2011, there was a 1.5-month anoxic period in the hypolimnion, and it could be argued that the aeration measure was not strong enough to alleviate anoxia and reduce redox-dependent $\mathrm{P}$ release and its symptoms. In 2016, in turn, mixing aeration provided dissolved oxygen in nearbottom waters and anoxia was avoided. Despite this, the highest deposits of organic material into the deep zones of the lake were observed. It seems that in 2011, it was not possible to provide enough oxygen to the hypolimnion by artificial aeration to compensate the increased oxygen demand of enhanced degradation as discussed in the earlier studies of Ashley (1983) and Horppila et al. (2015). Additionally, intensifying the aeration treatment is not a relevant option in Enonselkä, since the results of 2016 proved that the weakening of the water column stability and especially the destratification in the middle of the growth season enhances the unwanted effects of rapid nutrient recycling and excess production of organic material. Such a development would force a lake that is normally dimictic to the direction of a typical shallow eutrophic lake which can be highly productive due to intensive organic matter mineralisation and efficient recycling of nutrients resulting from their polymictic nature (Żbikowski et al., 2019).

\section{Conclusions}

Mixing aeration seemed to increase the degradation of settling organic material in the Enonselkä basin in a warm summer. However, the sedimentation rate of organic material significantly increased (1.4-fold) in the deep zones of the lake and oxygen deficit was not avoided due to increased oxygen consumption. Intensifying the treatment is not a relevant option, since in a cooler summer, mixing aeration caused destratification in the middle of the growth season and resulted in three times higher sedimentation rates of organic material compared with the reference year. 
Increased sediment focusing due to weaker water column stability in the aerated years was the major reason behind the strongly increased sedimentation rates observed in the deep zones. An aeration-induced increase in hypolimnetic temperature and turbulence enhanced nutrient recycling in the water column. Enhanced nutrient recycling together with the weakening of the water column stability and increased redistribution of the settling material resulted in an increased primary production and higher amounts of organic material reaching the lake bottom, as indicated by the increased sedimentation rates of carbon and nitrogen. Thus, 7 years of aeration did not change the quality of the surface sediment in the aerated deep zones of the lake. Most likely, the oxygen consumption potential of settling material remained unaffected, and it seems that although the problem of anoxia and redox-dependent internal $\mathrm{P}$ loading may partly be alleviated with mixing aeration, the method is not leading to a lower trophic level of the Enonselkä basin due to an enhanced nutrient recycling in the water column.

Acknowledgements Open access funding provided by University of Helsinki including Helsinki University Central Hospital. This work was supported by the Vesijärvi Foundation, Maa- ja vesitekniikan tuki ry (Grant Number: 33899), and City of Lahti.

Open Access This article is licensed under a Creative Commons Attribution 4.0 International License, which permits use, sharing, adaptation, distribution and reproduction in any medium or format, as long as you give appropriate credit to the original author(s) and the source, provide a link to the Creative Commons licence, and indicate if changes were made. The images or other third party material in this article are included in the article's Creative Commons licence, unless indicated otherwise in a credit line to the material. If material is not included in the article's Creative Commons licence and your intended use is not permitted by statutory regulation or exceeds the permitted use, you will need to obtain permission directly from the copyright holder. To view a copy of this licence, visit http://creativecommons.org/licenses/by/4.0/http://creativecommons.org/licenses/by/4.0/.

\section{References}

Ashley, K. L., 1983. Hypolimnetic aeration of a naturally eutrophic lake: physical and chemical effects. Canadian Journal of Fisheries and Aquatic Sciences 40: 1343-1359.

Bendtsen, J., K. E. Gustafsson, J. Lehtoranta, E. Saarijärvi, K. Rasmus \& H. Pitkänen, 2013. Modeling and tracer release experiment on forced buoyant plume convection from coastal oxygenation. Boreal Environment Research 18: $37-52$.

Bergström, I., P. Kortelainen, J. Sarvala \& K. Salonen, 2010. Effects of temperature and sediment properties on benthic $\mathrm{CO}_{2}$ production in an oligotrophic boreal lake. Freshwater Biology 5: 1747-1757.

Beutel, M. W., 2006. Inhibition of ammonia release from anoxic profundal sediments in lakes using hypolimnetic oxygenation. Ecological Engineering 28: 271-279.

Beutel, M. W. \& A. J. Horne, 1999. A review of the effects of hypolimnetic oxygenation on lake and reservoir water quality. Lake and Reservoir Management 15: 285-297.

Blais, J. M. \& J. Kalff, 1995. The influence of lake morphometry on sediment focusing. Limnology and Oceanography 40 : 582-588.

Bloesch, J. \& N. M. Burns, 1980. A critical review of sedimentation trap technique. Schweizerische Zeitschrift für Hydrologie 42: 15-55.

Bloesch, J. \& U. Uehlinger, 1986. Horizontal sedimentation differences in a eutrophic Swiss Lake. Limnology and Oceanography 31: 94-1109.

Boström, B., M. Jansson \& C. Forsberg, 1982. Phosphorus release from lake sediments. Archiv für Hydrobiologie Beiheft Ergebnisse der Limnologie 18: 5-59.

Buhvestova, O., J. Niemistö, J. Horppila, K. Kangur \& M. Haldna, 2013. Sedimentation and resuspension dynamics in Lake Vesijärvi (Finland): comparison of temporal and spatial variations of sediment fluxes in deep and shallow areas. Fundamental and Applied Limnology 182: 297-307.

Cooke, G. D., E. B. Welch, S. A. Peterson \& S. A. Nichols, 2005. Restoration and Management of Lakes and Reservoirs. Taylor and Francis, Boca Raton.

Dent, S. R., M. W. Beutel, P. Gantzer \& B. C. Moore, 2014. Response of methylmercury, total mercury, iron and manganese to oxygenation of an anoxic hypolimnion in North Twin Lake, Washington. Lake and Reservoir Management 30: 119-130.

Engstrom, D. R. \& D. I. Wright, 2002. Sedimentological effects of aeration-induced lake circulation. Lake and Reservoir Management 18: 210-214.

Gantzer, P. A., L. D. Bryant \& J. C. Little, 2009. Effect of hypolimnetic oxygenation on oxygen depletion rates in two water-supply reservoirs. Water Research 43: 1700-1710.

Gasith, A., 1975. Tripton sedimentation in eutrophic lakes simple correction for the resuspended matter. Verh. Int. Verein. Limnol. 19: 116-122.

Gälman, V., J. Rydberg, S. S. de-Luna, R. Bindler \& I. Renberg, 2008. Carbon and nitrogen loss rates during aging of lake sediment: changes over 27 years studied in varved lake sediment. Limnology and Oceanography 53: 1076-1082.

Hansen, K., 1961. Lake types and lake sediments. Verh. Int. Verein. limnol. 14: 285-290.

Harper, D., 1992. Eutrophication of Freshwaters: Principles, Problems and Restoration. Chapman \& Hall, London: 327.

Holmroos, H., J. Horppila, S. Laakso, J. Niemistö \& S. Hietanen, 2016. Aeration-induced changes in temperature and nitrogen dynamics in a dimictic lake. Journal of Environmental Quality 45: 1359-1366.

Horppila, J., P. Köngäs, J. Niemistö \& S. Hietanen, 2015. Oxygen flux and penetration depth in the sediments of 
aerated and non-aerated lake basins. International Review of Hydrobiology 100: 106-115.

Horppila, J., H. Holmroos, J. Niemistö, I. Massa, N. Nygrén, P. Schönach, P. Tapio \& O. Tammeorg, 2017. Variations of internal phosphorus loading and water quality in a hypertrophic lake during 40 years of different management efforts. Ecological Engineering 103: 264-274.

Jensen, H. S. \& F. O. Andersen, 1992. Importance of temperature, nitrate, and $\mathrm{pH}$ for phosphate release from aerobic sediments of four shallow eutrophic lakes. Limnology and Oceanography 37: 577-589.

Jones, J. G., 1976. The microbiology and decomposition of seston in open water and experimental enclosures in a productive lake. The Journal of Ecology 64: 241-278.

Kairesalo, T., S. Laine, E. Luokkanen, T. Malinen \& J. Keto, 1999. Direct and indirect mechanisms behind successful biomanipulation. Hydrobiologia 395(396): 99-106.

Keto, J. \& I. Sammalkorpi, 1988. A fading recovery: a conceptual model for Lake Vesijärvi management and research. Aqua Fennica 18: 193-204.

Koski-Vähälä, J., H. Hartikainen \& T. Kairesalo, 2000. Resuspension in regulating sedimentation dynamics in Lake Vesijärvi. Archiv für Hydrobiologie 148: 357-381.

Koyama, T. \& T. Tomino, 1967. Decomposition process of organic carbon and nitrogen in lake water. Geochemical Journal 1: 109-124.

Kuha, J. K., A. H. Palomäki, J. T. Keskinen \& J. S. Karjalainen, 2016. Negligible effect of hypolimnetic oxygenation on the trophic state of Lake Jyväsjärvi, Finland. Limnologica 58: $1-6$.

Kuoppamäki, K. Vesijärven eläinplanktonin seurantatutkimus 1991-2016. https://www.vesijarvi.fi/wp-content/uploads/ 2019/05/2016_k_kuoppamaki_elainplankton-raportti_ 2016.pdf (In Finnish).

Likens, G. E. \& M. B. Davis, 1975. Post-glacial history of Mirror Lake and its watershed in New-Hampshire, U.S.A. an initial report. Verhandlungen der Internationalen Vereinigung für Theoretische und Angewandte Limnologie 19: 982-993.

Lappalainen, K. M., 1994. Positive changes in oxygen and nutrient contents in two Finnish lakes induced by Mixox hypolimnetic oxygenation method. Verhandlungen der Internationalen Vereinigung für Theoretische und Angewandte Limnologie 25: 2510-2513.

Marsden, W. M., 1989. Lake restoration by reducing external phosphorus load, the influence of sediment phosphorus release. Freshwater Biology 21: 139-162.

Matinvesi, J., 1996. The change of sediment composition during recovery of two Finnish lakes induced by waste water purification and lake oxygenation. Hydrobiologia 335: 193-202.

Mortimer, C. H., 1941. The exchange of dissolved substances between mud and water in lakes. Journal of Ecology 29: 280-329.

Moore, B. C., B. K. Cross, E. M. Clegg, B. P. Lanouette, M. Skinner, E. Preece, A. Child, P. Gantzer, E. Shallenberger, D. Christensen \& B. Nine, 2014. Hypolimnetic oxygenation in Twin Lakes, WA. Part I: Distribution and movement of trout. Lake and Reservoir Management 30: 226-239.

Niemistö, J., P. Köngäs, L. Härkönen \& J. Horppila, 2016. Hypolimnetic aeration intensifies phosphorus recycling and increases organic material sedimentation in a stratifying lake: effects through increased temperature and turbulence. Boreal Environment Research 21: 571-587.

Pennington, W. \& T. G. Tutin, 1974. Seston and sediment formation in five Lake District lakes. The Journal of Ecology 62: 215-251.

Renberg, I. \& H. Hansson, 2008. The HTH sediment corer. Journal of Paleolimnology 40: 655-659.

Rose, A. H., 1967. Thermobiology. Academic Press, London.

Ruuhijärvi, J., Malinen, T., Kuoppamäki, K., Ala-Opas, P. and Vinni, M. 2019. Responses of food web to hypolimnetic aeration in Lake Vesijärvi. This issue

Salmi, P., I. Malin \& K. Salonen, 2014. Pumping of epilimnetic water into hypolimnion improves oxygen but not necessarily nutrient conditions in a lake recovering from eutrophication. Inland Waters 4: 425-434.

Sampei, Y. \& E. Matsumoto, 2001. C/N ratios in a sediment core from Nakaumi Lagoon, southwest Japan. Usefulness as an organic source indicator. Geochemical Journal 35: 189-205.

SAS Institute Inc, 2008. SAS OnlineDoc, version 8. SAS Institute Inc., Cary, NC.

Tattari, S. \& J. Linjama, 2004. Vesistöalueen kuormituksen arviointi. Vesitalous 4: 26-30.

Wetzel, R. G., 2001. Limnology: lake and river ecosystems. Gulf Professional Publishing, Houston.

Żbikowski, J., T. Simčič, F. Pajk, M. Poznańska-Kakareko, T. Kakareko \& J. Kobak, 2019. Respiration rates in shallow lakes of different types: contribution of benthic microorganisms, macrophytes, plankton and macrozoobenthos. Hydrobiologia 828: 117-136.

Publisher's Note Springer Nature remains neutral with regard to jurisdictional claims in published maps and institutional affiliations. 